\title{
DIFFERENCES IN SPATIAL STRUCTURE OF AGRICULTURAL AREAS IN VILLAGES OF COMMUNE OF BILGORAJ WITH REGARD TO LAND FRAGMENTATION
}

\author{
Przemyslaw Len \\ University of Life Sciences in Lublin, Poland \\ przemyslaw.len@up.lublin.pl
}

\begin{abstract}
The current state of agricultural production space is the outcome of centuries of human activity, as conditioned by socio-economic, legal, and political factors. The characteristic features of the spatial layout of land, which has been shaped in this historical process in the rural areas of southern and south-eastern Poland, are farms divided into a large number of parcels, lack of access to parcels, irregular shapes of parcels, and their scattering in space. Rural areas in Poland are in need of profound structural changes related to agricultural production, the size of agricultural holdings, the distribution of farmland in agricultural holdings, as well as the demographic, spatial and institutional structure of those areas. Spatial and economic studies of rural areas often use the method of grouping individual villages by shared features into larger typological classes. Such a division is possible because rural areas are characterised by both diversity and similarity. Identification of areas with the largest possible similarity of features facilitates analysis and allows one to capture the spatial diversity of an area. The paper presents the degree of land fragmentation in 30 villages of the commune of Bitgoraj located in the Lublin Voivodeship in eastern Poland. The research area covered 15,635.60 ha of farmland divided administratively into 36,620 land parcels (cadastral plots). Fragmentation was measured using the synthetic index of fragmentation of land parcels. The index was used to identify villages, which were similar in terms of the number and area of parcels in the parcel-area groups adopted in this study. The types of villages identified in the study vary in terms of the degree of fragmentation, which may be used as one of the criteria for determining the order, in which the villages should be subjected to land consolidation and exchange.
\end{abstract}

Keywords: land consolidation, rural areas, defective spatial structure of agricultural land.

\section{Introduction}

Poland faces a large problem related to the fragmentation of land, i.e. the situation in which numerous single farm holdings consist of several separate plots. Often, the plots are spatially separated and sometimes they are even several kilometres apart, which significantly increases production costs [1]. Apart from the excessive fragmentation of land, there are also the problems of scattering and unfavourable (irregular or elongated) shape of land parcels (cadastral plots). These factors hamper profitable agricultural production. To make matters worse, the existing network of field access roads does not allow access by modern agricultural machines and vehicles. This situation clearly calls for the adoption and implementation of consolidation measures in the most highly fragmented areas, which will improve the spatial structure of land. The problems discussed are not unique to Poland and affect many countries in Europe and around the world [2-7]. In Poland, farmland with the most defective spatial structure is mainly found in the eastern [8] and south-eastern parts of the country $[9 ; 10]$.

The defects are an obstacle to establishing a full-fledged real estate cadastre [11-15]. Even more importantly, they lead to higher costs incurred in crop production. Moreover, the defective spatial structure hinders effective use of land, thus reducing productivity [16]. Income from agricultural production can be reduced by up to $30 \%$ as a result of excessively small size and unfavourable shape of plots [17]. The defects in the layout of agricultural space, however, can be removed with the aid of land consolidation and exchange measures. Too many plots in one farm and the relatively small area of those plots are some of the main reasons for implementing land consolidation interventions [18]. Consolidation provides the possibility of reclaiming agriculturally useless land, i.e. finding alternative uses for the so-called problem areas of agriculture [19;20].

The goal of the present study was to determine the degree of land fragmentation and the concentration of fragmented areas in the villages of the Biłgoraj commune in the Lublin Province (Fig. 1).

\section{Materials and methods}

The study covered 30 out of the 31 villages of the Biłgoraj commune (Teodorówka was excluded because no cadastre data were available for that village). For each village, the number of plots and the surface areas of plots were determined in specified size (surface area) ranges. The five plot size groups 
identified in the study showed great diversity. To better analyse these groups, a synthetic index of fragmentation was calculated, which was then used to distinguish five types of villages which differed with respect to the degree of fragmentation. The study area covered 26,258.72 ha of farmland divided administratively into 45,525 land parcels (cadastral plots).

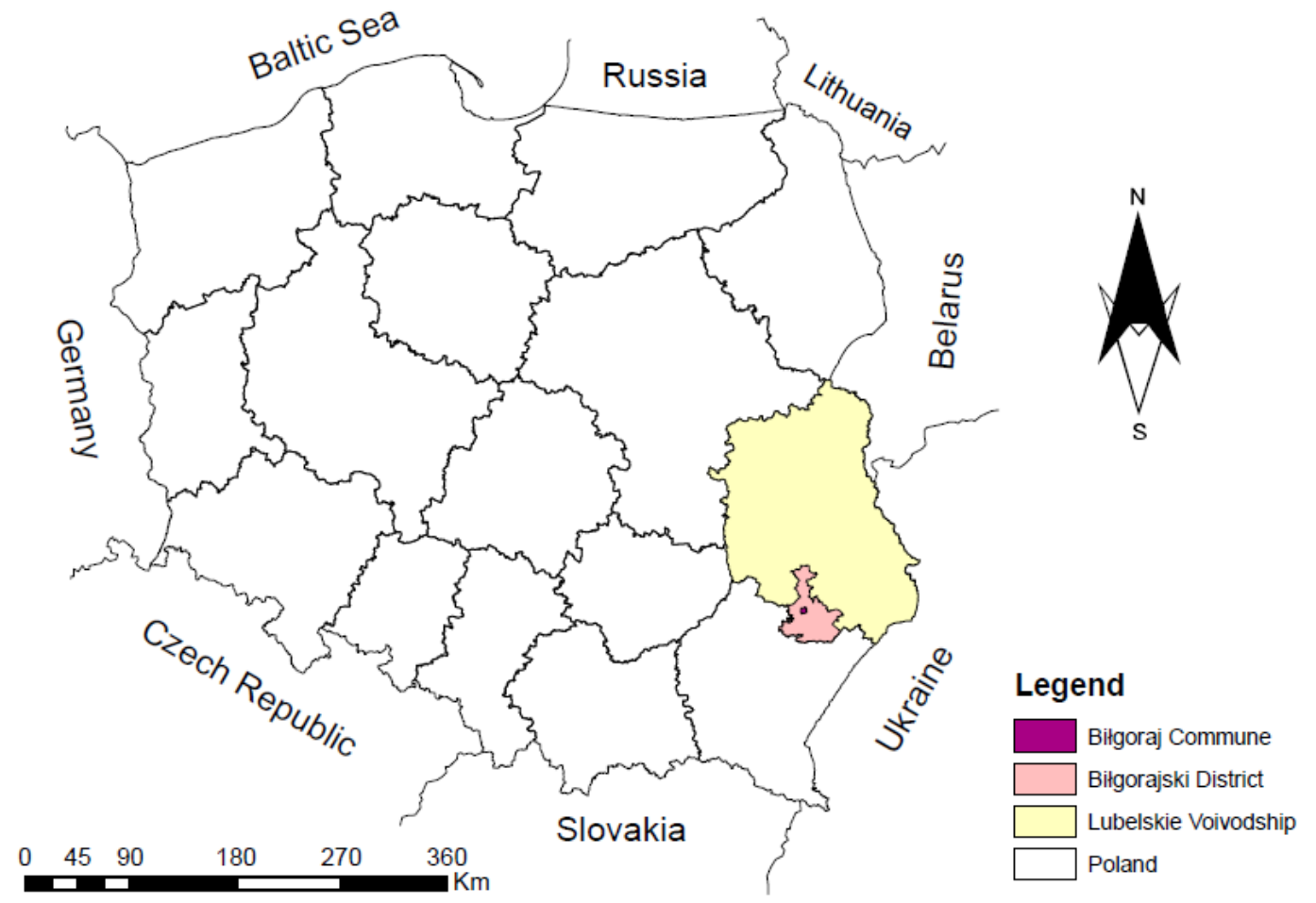

Fig. 1. Geographical situation of study area

Spatial and economic studies of rural areas often use the method of grouping individual villages by shared features into larger typological classes. Such clustering is possible because rural areas are characterised by both diversity and similarity. Identification of areas with the largest possible similarity of features facilitates analysis and allows one to capture the spatial diversity of an area [21].

With this in mind, in the present study, five types of villages, which were similar in terms of the degree of land fragmentation, were identified by calculating the synthetic index of land fragmentation using the formula proposed by Noga and Len [22]. The index was calculated based on data regarding the number and area of cadastral plots in five size ranges: up to $0.10 \mathrm{ha}, 0.11-0.30 \mathrm{ha}, 0.31-0.60 \mathrm{ha}$, 0.61-1.00 ha, and over 1.01 ha. The five size ranges were identified by ordering plots in each village by surface area from smallest to largest. A weight was assigned to each range: 1 to the range of up to 0.10 ha, 2 to $0.10-0.30$ ha, 3 to $0.31-0.60$ ha, 4 to $0.61-1.00 \mathrm{ha}$, and 5 to the range of above 1.01 ha. The fragmentation index was calculated on the basis of the following formula:

$$
W_{R}=\frac{\sum_{i=1}^{n}\left(x_{n} \cdot l_{n}\right)}{P},
$$

where $x_{n}$ - surface area of plots within the specified size ranges;

$l_{n}$ - weight for each of the five size ranges, 1-5;

$P$ - total area of privately owned land in the locality.

By calculating the fragmentation index for all the investigated villages, we were able to identify five village types characterized by the following values of the index: type I - up to 3.25 ; type II 3.26-3.75; type III - 3.76-4.00; type IV - 4.01-4.25, and type V - over 4.26.

The data characterizing each of the five village types are given in Table 1, and the spatial distribution of villages by type is shown in Fig. 2. As it can be seen in the Table, type I includes four villages occupying an area of 1289.18641 ha and representing $8.3 \%$ of the total area of the commune 
of Biłgoraj. This area is divided into 4,834 cadastral plots, which constitute $13.2 \%$ of the total number of all plots. The average plot size is 0.2685 ha. Three of the four villages are located in the direct vicinity of the town of Biłgoraj. The fourth village is located in the north-eastern part of the commune.

\section{Characteristics of types of villages}

Table 1

\begin{tabular}{|c|c|c|c|c|c|c|c|c|}
\hline \multirow[t]{2}{*}{ No. } & \multirow[t]{2}{*}{$\begin{array}{l}\text { Village } \\
\text { type }\end{array}$} & \multicolumn{2}{|c|}{$\begin{array}{l}\text { Number of } \\
\text { villages }\end{array}$} & \multicolumn{2}{|c|}{ Area } & \multicolumn{2}{|c|}{$\begin{array}{c}\text { Number of } \\
\text { plots }\end{array}$} & \multirow[t]{2}{*}{\begin{tabular}{|c} 
Mean \\
plot area \\
ha \\
\end{tabular}} \\
\hline & & Number & $\%$ & Number & $\%$ & Number & $\%$ & \\
\hline 1 & I & 4 & 13.3 & 1298.18641 & 8.3 & 4834 & 13.2 & 0.2685 \\
\hline 2 & II & 13 & 43.3 & 6007.27135 & 38.4 & 18458 & 50.4 & 0.3255 \\
\hline 3 & III & 5 & 16.7 & 1974.38927 & 12.6 & 4141 & 11.3 & 0.4768 \\
\hline 4 & IV & 4 & 13.3 & 3082.93869 & 19.7 & 5518 & 15.1 & 0.5586 \\
\hline 5 & $\mathrm{~V}$ & 4 & 13.3 & 3272.81735 & 20.9 & 3669 & 10.0 & 0.8918 \\
\hline & Total & 30 & 100.0 & 15635.6031 & 100 & 36620 & 100.0 & - \\
\hline
\end{tabular}

Type II, comprises the largest number of villages (13), which are located in the central and eastern part of the commune. (Fig. 2). Villages in this type-category occupy an area of 6277.27135 ha, which constitutes $38.4 \%$ of the studied area. There are 18,458 cadastral plots in those villages, which constitute $50.4 \%$ of all privately owned plots in the commune of Biłgoraj. The mean surface area of a plot for this type of village is 0.3255 ha. Type II villages are located in the immediate or close vicinity of the district (poviat) town of Biłgoraj, which is the administrative, cultural and industrial centre of the studied area. Easy access to Biłgoraj and the employment opportunities offered by the town have clearly affected the degree of fragmentation of land belonging to private owners in this area. Nowadays, urban sprawl, or suburbanization, is observed more and more often in Poland. Studies carried out in this subject area have shown that people, who move to rural areas, are mostly professionally active individuals, owing to which the proportion of people in the productive age group increases in those places [23].

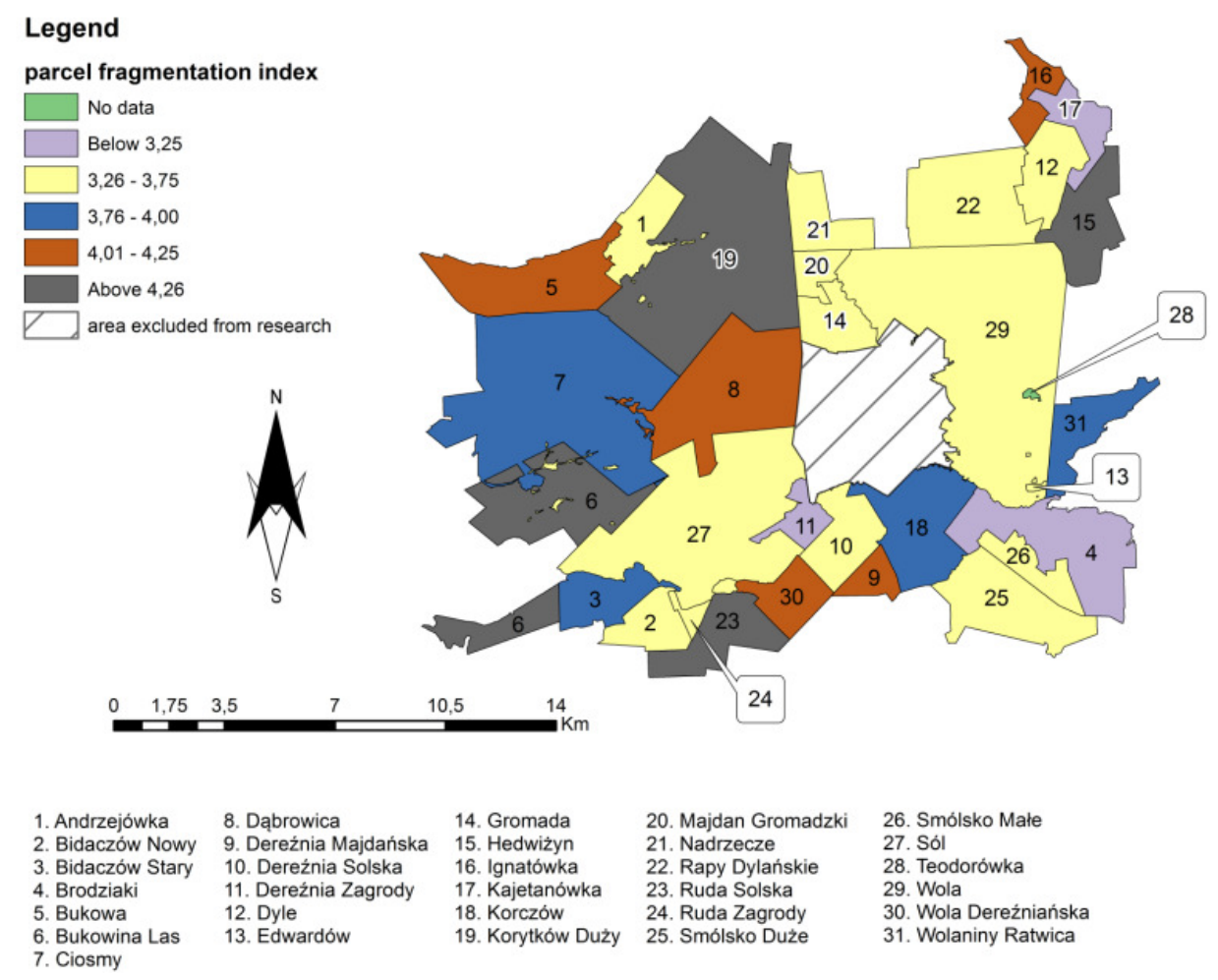

Fig. 2. Commune of Bitgoraj. Village types by degree of fragmentation of privately owned land

Type III includes four villages with an area of 1974.38927 ha, which make up $12.6 \%$ of the entire study area. The average size of a plot in this type of village is 0.4768 ha, which is larger than in type II 
villages. Type IV comprises five villages with an area of 3082.93869 ha, which occupy $19.7 \%$ of the total area of the studied commune. The mean plot area is 0.5586 ha. Type $\mathrm{V}$ also includes four villages, with a total area of 3272.81735 ha, which represent as much as $20.9 \%$ of the total area of the commune. This area is divided into 3,669 cadastral plots, which constitute only $10.0 \%$ of the total number of plots. The average plot area is as much as 0.8918 ha. To sum up, it should be stated that the division into five types of villages fully reflects the state of fragmentation of plots of land in the studied area.

\section{Results and discussion}

\section{The number and area of plots in the villages by fragmentation-type}

The five types of village identified in the study vary substantially with regard to the degree of fragmentation of privately owned land measured as the number of plots. The data are given in Table 2 . Particularly large differences in the number of plots in a given village type are observed when one considers the individual size groups. As the data in Table 2 indicate, the first four types of village have the highest number of plots in the size range of 0.11-0.30 ha; this trend only changes in the last village type, in which the highest percentage of plots are plots larger than 1.01 ha. In turn, the largest plots in the first two size ranges constitute $7.4 \%$ and $7.1 \%$ of all plots in those ranges, and the percentage share of plots of this size becomes larger for each successive size range. It is worth noting that in the first three village types, there is a high percentage of plots in the area range of 0.00-0.10 ha, which means that the degree of land fragmentation in those villages is very high.

Table 2

Number of plots in each of the five village types

\begin{tabular}{|c|c|c|c|c|c|c|c|c|c|c|c|}
\hline \multirow{3}{*}{ No. } & \multirow{3}{*}{$\begin{array}{c}\text { Size } \\
\text { range, } \\
\text { ha }\end{array}$} & \multicolumn{10}{|c|}{ Village type } \\
\hline & & \multicolumn{2}{|c|}{$\mathrm{I}$} & \multicolumn{2}{|c|}{ II } & \multicolumn{2}{|c|}{ III } & \multicolumn{2}{|c|}{ IV } & \multicolumn{2}{|c|}{$\mathrm{V}$} \\
\hline & & $\begin{array}{l}\text { Number } \\
\text { of plots }\end{array}$ & $\%$ & $\begin{array}{l}\text { Number } \\
\text { of plots }\end{array}$ & $\%$ & $\begin{array}{c}\text { Number } \\
\text { of plots }\end{array}$ & $\%$ & $\begin{array}{l}\text { Number } \\
\text { of plots }\end{array}$ & $\%$ & $\begin{array}{l}\text { Number } \\
\text { of plots }\end{array}$ & $\%$ \\
\hline 1 & $\begin{array}{c}0.00- \\
0.10\end{array}$ & 1433 & 14.4 & 2050 & 16.8 & 926 & 13.3 & 290 & 8.2 & 135 & 3.4 \\
\hline 2 & $\begin{array}{l}0.11- \\
0.30\end{array}$ & 5767 & 57.9 & 6667 & 54.7 & 3469 & 49.7 & 1475 & 41.5 & 1080 & 27.4 \\
\hline 3 & $\begin{array}{c}0.31- \\
0.60 \\
\end{array}$ & 938 & 9.4 & 1253 & 10.3 & 938 & 13.5 & 499 & 14.1 & 513 & 13.0 \\
\hline 4 & $0.61-1.0$ & 1082 & 10.9 & 1364 & 11.2 & 737 & 10.6 & 665 & 18.7 & 903 & 22.9 \\
\hline 5 & $<1.01$ & 737 & 7.4 & 861 & 7.1 & 904 & 13.0 & 623 & 17.5 & 1313 & 33.3 \\
\hline \multicolumn{2}{|c|}{ Total } & 9956 & 100.0 & 12194 & 100.0 & 6973 & 100.0 & 3552 & 100.0 & 3944 & 100.0 \\
\hline
\end{tabular}

The number of parcels in the individual village types and size ranges expressed as percent of all plots corresponds with the size of the plots, as illustrated in the table. The area of a plot determines how much labour input it requires. In countries of the European Union, plot areas range from 0.8 to 10.0 ha. How large the differences in plot size are depends on the area of the farm and what type of activity it specializes in, the degree of mechanization, topography, and invariant features of the terrain. As the surface area of plots increases, the number of on-farm working hours decreases, and the deductions from plot price also become smaller, according to research done in the EU countries [24]. A characteristic feature of the area studied, as shown in Table 3, is that the highest percentage of land area in the first three types of villages is occupied by plots with sizes in the range of 0.11-0.30 (from $49.1 \%$ in type III villages up to $57.1 \%$ in type I villages). The first three types of villages have a very high percentage share of land parcels with sizes in the range of $0-0.10$. The results show that as one moves from type I to type IV villages, the percentage of plots in the area range of up to 0.10 ha decreases from $15.6 \%$ to $3.0 \%$, respectively, and the percentage of plots in the range of $0.11-0.30$ ha falls down from $57.1 \%$ to $25.3 \%$. 
Size of land parcels in each of the five village types

\begin{tabular}{|c|c|c|c|c|c|c|c|c|c|c|c|}
\hline \multirow{2}{*}{ No. } & \multirow{2}{*}{$\begin{array}{c}\text { Size } \\
\text { range, } \\
\text { ha }\end{array}$} & \multicolumn{9}{|c|}{ I } & \multicolumn{9}{|c|}{ II } & \multicolumn{2}{c|}{ III } & \multicolumn{2}{c|}{ IV } & \multicolumn{3}{c|}{ V } \\
\cline { 3 - 12 } & Plot area & $\%$ & Plot area & $\%$ & Plot area & $\%$ & Plot area & $\%$ & Plot area & $\%$ \\
\hline 1 & $0-0.10$ & 84.9564 & 15.6 & 387.9800 & 16.5 & 394.1121 & 12.9 & 222.2250 & 7.9 & 208.9129 & 3.0 \\
\hline 2 & $\begin{array}{c}0.11- \\
0.30\end{array}$ & 310.1540 & 57.1 & 1290.9536 & 54.8 & 1505.9030 & 49.1 & 1160.5636 & 41.5 & 1739.6972 & 25.3 \\
\hline 3 & $\begin{array}{c}0.31- \\
0.60\end{array}$ & 50.5237 & 9.3 & 248.5971 & 10.5 & 413.7214 & 13.5 & 388.0692 & 13.9 & 873.4778 & 12.7 \\
\hline 4 & $\begin{array}{c}0.61- \\
1.00\end{array}$ & 58.6194 & 10.8 & 257.5301 & 10.9 & 330.8633 & 10.8 & 536.6450 & 19.2 & 1573.3715 & 22.9 \\
\hline 5 & $<1.01$ & 39.2238 & 7.2 & 171.8820 & 7.3 & 420.2101 & 13.7 & 492.2799 & 17.6 & 2475.1309 & 36.0 \\
\hline \multicolumn{2}{|c|}{ Total } & 543.4774 & 100.0 & 2356.9428 & 100.0 & 3064.8100 & 100.0 & 2799.7827 & 100.0 & 6870.5903 & 100.0 \\
\hline
\end{tabular}

\section{Conclusions}

As the large fragmentation of farmland in the villages under study shows, the spatial structure of privately owned land in that territory is very defective. The synthetic fragmentation index allowed us to identify five types of villages, which are similar in respect of the number and area of parcels in the size ranges adopted in this study. The spatial distribution of the villages classified in the particular types is closely related to their natural conditions, location and transport connection with the town of Biłgoraj. Type I and II villages, which are located in the close vicinity of Biłgoraj, are characterized by the largest fragmentation of land. The farther from the town a village is situated and the less varied its topography, the smaller the fragmentation of its farmland. The observed tendency of fragmentation of land parcels to become smaller as one goes from type I to type II villages can be used as a criterion in planning consolidation interventions in those villages.

The implementation of land consolidation and exchange measures for eliminating the existing fragmentation of privately owned land will, of course, depend on the involvement and activity of the authorities at all levels of government and self-government administration and the rural community itself.

\section{References}

[1] Noga K. Metodyka programowania i realizacji prac scalenia i wymiany gruntów w ujęciu kompleksowym (Methods for programming and implementation of land consolidation and exchange activities: A comprehensive perspective). AR. Kraków, 2001. (In Polish)

[2] Hartvigsen M. Land Consolidation in Central and Eastern European Countries. Shaping the Change. XXIII FIG Congress Munich, Germany, October 8-13, 2006.

[3] Hartvigsen M. Land Reform and Land Consolidation in Central and Eastern Europe after 1989: Experiences and Perspectives. Aalborg Universitetsforlag. (Ph.d.-serien for Det TekniskNaturvidenskabelige Fakultet, Aalborg Universitet), 2015.

[4] Hudecová L., Geisse R., Vardžáková M., Turan P. Calculation of land fragmentation. Kartografické listy / Cartographic letters, 2016, 24 (1), 2016, pp. 12-22.

[5] van Hung P., MacAulay G.T., Marsh S.P. The economics of land fragmentation in the north of Vietnam. Australian Journal of Agricultural \& Resource Economics, 51(2), 2007, pp. 195-211.

[6] Rahman S., Rahman M. Impact of land fragmentation and resource ownership on productivity and efficiency: The case of rice producers in Bangladesh. Land Use Policy, 26, 2008, pp. 95-103.

[7] Tan S., Heerink N., Qu F. Land fragmentation and its driving forces in China. Land Use Policy, 23(3), 2006, pp. 272-285.

[8] Strek Z. Engineering for rural development analysis of demand for land consolidation in Milejów commune, Łęczna district. Engineering for Rural Development, Jelgava, 24.-26.05.2017, pp. 593-599, DOI: 10.22616/ERDev2017.16.N119. 
[9] Leń P., Król Z. Analysis of economic and environmental effects of land consolidation on the example of Hucisko village . Journal of Ecological Engineering. Volume 17, Issue 5, Nov. 2016, pp. 232-239. DOI: $10.12911 / 22998993 / 65090$

[10] Wójcik-Leń J., Stręk Ż., 2017. Proposal for land consolidation project solutions for selected problem areas. World Multidisciplinary Earth Sciences Symposium (WMESS 2017). Earth and Environmental Science 95 (2017) 032016 DOI :10.1088/1755-1315/95/3/032016.

[11] Dawidowicz A., Zrobek R. Analysis of concepts of cadastral system technological development. In: Proceedings of the 9th International Conference Environmental Engineering - Selected Papers., 2014. DOI: 10.3846/enviro.2014.201.

[12] Dawidowicz A., Zrobek R. Hierarchical development of the spatial data infrastructures as a globalization trend. In: Proceedings of the Baltic Geodetic Congress, Geomatics 2016. DOI: 10.1109/BGC.Geomatics.2016.34.

[13] Dawidowicz A., Źróbek R. 2018. A methodological evaluation of the Polish cadastral system based on the global cadastral model. Land Use Policy 73, 2018, pp. 59-72. https://doi.org/10.1016/j.landusepol.2018.01.037

[14] Mika M. Proposals for changes in surveying-legal procedures for the needs of cadastre in Poland. Reports on Geodesy and Geoinformatics Volume: 102 Issue: 1, 2016, pp. 67-77

[15] Mika M. Interoperability cadastral data in the system approach .Journal of Ecological Engineering Volume: 18 Issue: 2, 2017, pp. 150-156

[16] Król Ż. Charakterystyka szachownicy gruntów o układzie wstęgowym na przykładzie miejscowości Brzeziny gmina Puchaczów. Infrastruktura i Ekologia Terenów Wiejskich. Nr II/2/2014. PAN, Oddział w Krakowie, 2014, pp. 423-435

[17] Hopfer A. (Ed.). Wycena nieruchomości [Property valuation]. ART in Olsztyn, 1991.

[18] Hopfer A., Urban M. Geodezyjne urządzanie terenów rolnych [Land surveying management of agricultural land]. PWN. Warszawa, 1984.

[19] Wójcik-Leń J., Sobolewska-Mikulska K. Specific features of development of selected agricultural problematic areas in the land consolidation process. Journal of Water and Land Development. No. 34, 2017, pp. 249-258. DOI: 10.1515/jwld-2017-0060.

[20] Wójcik-Leń J., Sobolewska-Mikulska K. Issues related to marginal lands with reference to selected agricultural problematic areas. Journal of Water and Land Development. No. 35, 2017, pp. 265-273. DOI: 10.1515/jwld-2017-0093.

[21] Noga K. Typologia wsi górskich dla potrzeb urządzenioworolnych (A typology of mountain villages for the needs of land management). Scientific Papers of Agricultural Academy, Geodezja, Issue 6, No. 155, Kraków 1979. (In Polish)

[22] Noga K., Leń P. 2010. Analiza rozdrobnienia gruntów indywidualnych we wsiach powiatu Brzozów. Infrastruktura i Ekologia Terenów Wiejskich. Nr 2010/ 03.

[23]Źróbek-Różańska A., Zysk E. Czy rozlewające się miasto odmładza podmiejską wieś? Studium podolsztyńskich gmin wiejskich (Does a sprawling city rejuvenate the suburban village? A study of rural communes near the city of Olsztyn. Village and agriculture), 16 (4), 2015, pp. 123-137. (In Polish)

[24] Noga K. Metodyka programowania prac scaleniowych i technologia ich wykonywania w terenach górskich (Na przykładzie beskidzkiej zlewni Soły) [Methodology for Programming Consolidation Activities and the Technology of Consolidating Land in mountainous areas. (The Example of the Beskid Catchment of the River Soła) Scientific Papers of Agricultural Academy, Treatises, Issue 143, Kraków 1990. (In Polish) 